\title{
Molecular Methods to Detect and Quantify Botryosphaeriaceae Inocula Associated With Grapevine Dieback in Australia
}

Regina Billones-Baaijens, ${ }^{\dagger}$ National Wine and Grape Industry Centre, School of Agricultural and Wine Sciences, Charles Sturt University, Wagga Wagga, NSW, Australia; José Ramón Úrbez-Torres, Summerland Research and Development Centre, Agriculture and Agri-Food Canada, Summerland, BC, Canada; Meifang Liu, National Wine and Grape Industry Centre, School of Agricultural and Wine Sciences, Charles Sturt University, Wagga Wagga, NSW, Australia; Matthew Ayres, South Australian Research and Development Institute, Adelaide, SA, Australia; Mark Sosnowski, South Australian Research and Development Institute, Adelaide, SA, Australia; and School of Agriculture, Food and Wine, The University of Adelaide, Waite Campus, Glen Osmond, SA, Australia; and Sandra Savocchia, National Wine and Grape Industry Centre, School of Agricultural and Wine Sciences, Charles Sturt University, Wagga Wagga, NSW, Australia

\begin{abstract}
Botryosphaeria dieback, caused by species of Botryosphaeriaceae, is an important grapevine trunk disease in Australia. Inocula produced by the pathogens are primarily dispersed by rain splash and wind and infect pruning wounds leading to cankers, dieback, and eventually death of vines. The objective of this study was to develop molecular tools to detect and quantify Botryosphaeriaceae inocula from the environment. These tools are essential for investigating spore dispersal patterns of Botryosphaeriaceae pathogens in Australian vineyards. DNA extraction protocols were evaluated and one modified protocol was found suitable for extracting Botryosphaeriaceae DNA from artificially and naturally inoculated Burkard volumetric spore

sampler tapes. Multispecies primers and a hydrolysis probe for quantitative PCR (qPCR) were further developed to detect and quantify Botryosphaeriaceae inocula from environmental samples. Specificity tests showed that the multispecies primers were able to amplify the DNA of 10 Botryosphaeriaceae species (58 isolates) found in Australia while none of the 27 nontarget fungal species (90 isolates) tested were amplified. The qPCR assay was suitable for amplifying purified DNA, synthetic DNA fragments (gBlocks), and mixed DNA from spore trap tapes. The qPCR method developed in this study was shown to be rapid and sensitive in detecting Botryosphaeriaceae inocula from the environment using spore traps.
\end{abstract}

Grapevine trunk diseases contribute to grapevine decline worldwide, reducing vineyard productivity and longevity. Botryosphaeria dieback, caused by several species of fungi from the family Botryosphaeriaceae (Úrbez-Torres 2011), is considered one of the most important trunk diseases of grapevines. These pathogens infect vines through pruning wounds and colonize the wood, leading to dieback and eventual death of the vine. The common internal wood symptom observed includes a wedge-shaped necrosis that is often associated with pruning wounds (Úrbez-Torres 2011). When the wound is cut open, wood staining of various shapes is visible that often reflects the position of pathogen entry into the wounds. The conidia of the Botryosphaeriaceae are released from pycnidia embedded in diseased woody parts of vines as well as in pruning debris left in the vineyard after pruning (van Niekerk et al. 2010). These conidia are dispersed primarily by rain splash and travel distances depending on the wind speed (Baskarathevan et al. 2013; Úrbez-Torres et al. 2010).

Surveys across Australia showed Botryosphaeria dieback to be prevalent in different wine growing regions, with 10 species of Botryosphaeriaceae found to be associated with the disease (Pitt et al. 2010, 2013; Qiu et al. 2011; Savocchia et al. 2007; Wunderlich et al. 2011). In warmer and more humid climates of Australia, such as those experienced in the Hunter Valley region of New South Wales (NSW), species of Botryosphaeriaceae have also been associated

${ }^{\dagger}$ Corresponding author: Regina Billones-Baaijens;

E-mail: rbaaijens@csu.edu.au

Funding: This research was funded by Australia's grape growers and winemakers through their investment body, Wine Australia, with matching funds from the Australian Government (SAR 1205).

Accepted for publication 12 February 2018.

(c) 2018 The American Phytopathological Society with bunch rots (Wunderlich et al. 2011). Wound susceptibility to trunk pathogens varies during the pruning season and among environments, and can persist up to 12 weeks (Serra et al. 2008; Úrbez-Torres and Gubler 2011; van Niekerk et al. 2011). Thus, understanding the spore dispersal patterns of these pathogens and the environmental factors that favor the release of these inocula will assist in identifying critical infection periods in vineyards. However, there are no published data available on the spore dispersal patterns of Botryosphaeriaceae pathogens in Australian vineyards to date.

According to research in other countries, the seasonal spore dispersal patterns for Botryosphaeriaceae pathogens from grapevines can vary significantly. Botryosphaeriaceae spores were trapped in high numbers in California following rain events and primarily during winter (Úrbez-Torres et al. 2010). However, spores were trapped throughout the year, but were most abundant in summer in New Zealand (Amponsah et al. 2009), from mid-spring to mid-autumn in France (Kuntzmann et al. 2009) and from late autumn to early spring in South Africa (van Niekerk et al. 2010) and Chile (Valencia et al. 2015). These conflicting data are most likely due to differences in climatic conditions between countries. Therefore, there is a need for further investigation of the spore dispersal patterns of these pathogens in Australian vineyards. This will assist in determining the timing of spore release by Botryosphaeriaceae pathogens throughout the growing season and, in particular, during the pruning season across different climatic regions of Australia.

Previous studies on the spore dispersal of Botryosphaeriaceae from other countries relied primarily on conventional techniques such as microscopy and culturing of the microorganisms on artificial media, which are extremely time consuming, and are limited in accuracy and sensitivity in detecting these pathogens from environmental samples (Kuntzmann et al. 2009; Úrbez-Torres et al. 2010; van Niekerk et al. 2010). In recent years, however, molecular techniques have been reported to be useful for detecting pathogens from different environmental samples because they are rapid and more sensitive than conventional techniques. The quantitative real-time PCR (qPCR) that utilizes fluorescence chemistry allows the 
detection and quantification of very low amounts of nucleic acids in a wide range of samples (Bustin et al. 2009). The qPCR has since been commonly used to detect airborne inoculum of different plant pathogens including Sclerotinia sclerotiorum in vegetable crops (Rogers et al. 2009), Mycosphaerella graminicola in wheat (Duvivier et al. 2013), Leptosphaeria maculans in canola (Van de Wouw et al. 2010), Botrytis cinerea in grapes (Diguta et al. 2010), and Sphaeropsis sapinea in pine species (Luchi et al. 2005). The qPCR assays have also been developed for the detection and quantification of the grapevine trunk disease pathogens, Phaeomoniella chlamydospora and Phaeoacremonium minimum (Martín et al. 2012), Eutypa lata, and Diplodia seriata-complex (Pouzoulet et al. 2017). However, all of these methods make use of species-specific primers and none can detect multiple targets in one reaction. A multiplex qPCR was recently developed to detect $P h$. chlamydospora and $P$. minimum in one qPCR reaction (Pouzoulet et al. 2013). Multi-species primers targeting species of Botryosphaeriaceae, developed in New Zealand (Ridgway et al. 2011) and Italy (Spagnolo et al. 2011), were found to be useful in detecting these pathogens from environmental samples. However, these primers were not specifically designed for qPCR. Since 10 species of Botryosphaeriaceae are known to be present in Australian vineyards, a multi-species qPCR assay that can detect all these pathogens in a single reaction will allow a rapid and more cost effective quantification of these pathogens.

The objective of this study was to develop molecular tools, particularly the design and optimization of a qPCR assay that can detect and quantify multiple species of Botryosphaeriaceae from the environment. This assay is essential for accurate detection and quantification of the inoculum of several Botryosphaeriaceae species from samples collected in Burkard volumetric spore sampler traps deployed in wine regions of Australia with differing climates.

\section{Materials and Methods}

PCR primer and probe development. Sequences of the ribosomal RNA (rRNA) and $\beta$-tubulin genes were retrieved from GenBank (https://www.ncbi.nlm.nih.gov/) for 10 species of Botryosphaeriaceae known to infect grapevines in Australia. The 47 reference sequences for Botryosphaeriaceae spp. included Botryosphaeria dothidea (4), Diplodia mutila (5), D. seriata (12), Dothiorella vidmadera (3), Lasiodiplodia theobromae (3), Neofusicoccum australe (5), N. luteum (5), N. parvum (5), N. ribis (1), and Spencermartinsia viticola (4). All sequences were aligned by ClustalW using MEGA7 (Kumar et al. 2016) to identify potential binding sites for the target species. The designed primers were tested for their theoretical specificity to their target species using MEGA7 and Primer-Blast (https://www.ncbi.nlm. nih.gov/tools/primer-blast/index.cgi) prior to in vitro testing. The primers were further tested for potential secondary structures using mfold (http://www.bioinfo.rpi.edu/applications/mfold/). A hydrolysis probe (TaqMan) was further designed for qPCR using the Beacon Designer 8 (Premier Biosoft, U.S.A.).

Fungal isolates. Fifty-eight isolates representing 10 species of Botryosphaeriaceae from the culture collections of the National Wine and Grape Industry Centre (NWGIC), Charles Sturt University (CSU); Agricultural Scientific Collections Unit, New South Wales Department of Primary Industries (NSW-DPI), Australia; and Summerland Research and Development Centre (SuRDC), Agriculture and Agri-Food Canada, were used to test the specificity of the designed primers (Table 1). These isolates were previously identified to species by partial DNA sequencing of the rRNA and $\beta$-tubulin genes (Pitt et al. 2010, 2013; Trouillas et al. 2011; Úrbez-Torres and O'Gorman 2016; Wunderlich et al. 2011). From the same culture collections, 90 fungal isolates of the 27 nontarget species isolated from grapevines including 38 Diatrypaceae isolates were also used in this study (Table 2). The identities of these nontarget isolates were confirmed by DNA sequencing of the ITS region of the ribosomal DNA (Pitt et al. 2010; Trouillas et al. 2011; Úrbez-Torres et al. 2014a, b; Wunderlich et al. 2011).

DNA extraction from pure cultures. Crude DNA samples from Australian cultures were extracted from the mycelia of all target and nontarget species (Table 1 and 2) using PrepMan Ultra (Applied Biosystems, U.K.) following the manufacturer's instructions. Except for the biotrophic fungus, Erysiphe necator, all isolates were grown on PDA (Oxoid, Hampshire, England) for 3 to 7 days at $25^{\circ} \mathrm{C}$ in total darkness. Mycelium ( $100 \mathrm{mg}$ ) was scraped from the edge of the colony for each isolate using a sterile pipette tip and transferred into a sterile 1.5-ml tube containing $100 \mu$ l of the PrepMan Ultra (Applied Biosystems, U.K.) preparation reagent. Mycelial suspensions were vortexed for $30 \mathrm{~s}$ and incubated at $95^{\circ} \mathrm{C}$ in a heat block for $10 \mathrm{~min}$. The tubes were centrifuged for $2 \mathrm{~min}$ at 3,220 $\times \mathrm{g}$ and $50 \mu \mathrm{l}$ of the supernatant was transferred to a new sterile 1.5 -ml tube and stored at $-20^{\circ} \mathrm{C}$ until used for PCR. For E. necator, mycelium was scraped directly from infected grapevine leaves using a fine paintbrush and used for extractions as described for pure cultures.

Genomic DNA (gDNA) samples from Australian cultures were further extracted from fungal mycelia for all the Botryosphaeriaceae species (Table 1) using both the Isolate II Plant DNA Kit (Bioline, U.K.) and the DNeasy Plant Mini Kit (Qiagen, Germany). Pure cultures of all species were grown in potato dextrose broth (PDB, Oxoid, Hampshire, England) at $25^{\circ} \mathrm{C}$ in total darkness for 3 days. Mycelia were separated from the broth using sterile Miracloth (Merck, Darmstadt, Germany), wrapped in sterile aluminum foil, snap-frozen in liquid nitrogen, and stored at $-80^{\circ} \mathrm{C}$ until required. Genomic DNA was extracted from frozen, ground mycelium following the manufacturer's instructions. For isolates from SuRDC, gDNA of isolates were extracted using the FastDNA Spin Kit (MP Biomedicals, U.S.A.). Pure cultures of all species were grown in PDA for 3 to 7 days, and gDNA was extracted from the aerial mycelium of each isolate following the manufacturer's instructions.

DNA concentrations for all gDNA were determined using a NanoDrop 2000 Spectrophotometer (Thermo Fisher Scientific, U.S.A.). The concentrations were further verified by loading $5 \mu l$ of each gDNA in $1.5 \%$ agarose (Bioline, U.K.) and separated by electrophoresis $(10 \mathrm{~V} / \mathrm{cm}$ for $55 \mathrm{~min}$ ) immersed in $1 \times$ TAE buffer ( $40 \mathrm{mM}$ Tris acetate, $2 \mathrm{mM}$ $\mathrm{Na}_{2}$ EDTA, pH 8.0). The Hyperladder $1 \mathrm{~Kb}$ (Bioline, U.K.) and High Mass Ladder (Invitrogen) were run in either the first or last lane of each gel, respectively. The gels were stained using $1 \times$ GelRed nucleic acid gel stain (Biotium, U.S.A.) and visualized under UV light using a Gel Doc XR+ Imaging System (BIO-RAD Laboratories, Pty, Ltd., U.S.A.). DNA mass per microliter of each gDNA sample was calculated using Image Lab 5.1 imaging software (BIO-RAD Laboratories, Pty, Ltd., U.S.A.) using the two mass ladders as references.

Primer optimization and sensitivity test by conventional PCR. The optimum annealing temperature for the primers was determined by conducting a gradient PCR on a thermal cycler (C100 Thermal Cycler, BIO-RAD Laboratories, Pty, Ltd., U.S.A.). The $25 \mu$ l PCR reactions contained 1× PCR buffer (Bioline, U.K.), $0.4 \mu \mathrm{M}$ of each primer (Geneworks, Pty. Ltd., Australia), 1.25 U of MyTaq DNA Polymerase (Bioline, U.K.), and $1 \mu \mathrm{l}$ of either crude or gDNA of two L. theobromae isolates (G31a and W200). The thermal cycling conditions were as follows: initial denaturation at $95^{\circ} \mathrm{C}$ for $5 \mathrm{~min}$, followed by 35 cycles of $30 \mathrm{~s}$ at $94^{\circ} \mathrm{C}, 30 \mathrm{~s}$ annealing (gradient run of $54^{\circ} \mathrm{C}$ to $64^{\circ} \mathrm{C}$ ) and $30 \mathrm{~s}$ at $72^{\circ} \mathrm{C}$, and a final extension of $72^{\circ} \mathrm{C}$ for $5 \mathrm{~min}$. Following PCR amplification, $5 \mu$ l of each PCR product was separated by electrophoresis $(10 \mathrm{~V} / \mathrm{cm}$ for $50 \mathrm{~min})$ in a $1 \%$ agarose gel (Bioline, U.K.) in $1 \times \mathrm{TAE}$ buffer. Gels were stained with $1 \times$ GelRed nucleic acid gel stain (Biotium, U.S.A.) and visualized under UV light using a Gel Doc XR+ Imaging System (BIO-RAD Laboratories, Pty, Ltd., U.S.A.).

The detection sensitivity for primers Bot-BtF1 and Bot-BtR1 was further tested by conventional PCR. The gDNA of $D$. seriata (DAR79990) and $N$. parvum (DAR78998) was serially diluted from $2 \mathrm{ng} / \mu \mathrm{l}$ to $20 \mathrm{fg} / \mu \mathrm{l}$ and $1 \mu \mathrm{l}$ of each dilution was used as a template using the optimum PCR reaction and thermal cycling condition previously described. The sensitivity of the primers was further assessed using nested PCR by initially amplifying the serially diluted template DNA using the Bt2a and Bt2b as external primers following the same thermal cycling conditions previously described (Glass and Donaldson 1995). The products from the first step PCR were diluted to 1:100 in nuclease-free water and $1 \mu \mathrm{l}$ was used as a template for the second step PCR using multispecies primers Bot-BtF1 and Bot-BtR1 as previously described.

Primer validation. To validate the results obtained from the laboratory at CSU in Australia, the primers were further tested for their specificity 
at the SuRDC Plant Pathology Laboratory in Summerland, British Columbia, Canada, in March to May 2016 using the SuRDC collection, which included isolates from Australia, Canada, the U.S.A., and ex-type specimens from the CBS-KNAW Culture Collection, The Netherlands (Tables 1 and 2) using the protocols described previously.
Quantitative PCR: SYBR Green qPCR. The multispecies primers Bot-BtF1 and Bot-BtR1 were initially tested using SYBR green chemistry. The qPCR was performed in $0.1 \mathrm{ml}$ strip tubes and caps (Qiagen, U.S.A.) using a RotorGene 6000 (Corbett Life Science, Qiagen, U.S.A.). Each $20 \mu \mathrm{l}$ reaction contained $10 \mu \mathrm{l}$ of $2 \times$ SsoAdvanced Universal

Table 1. Fungal isolates used for testing the specificity of Botryosphaeriaceae multispecies primers (Bot-BtF1 and Bot-BtR1) by conventional PCR

\begin{tabular}{|c|c|c|c|c|c|}
\hline Species & Isolate & Herbarium accession & Source (reference) & Country of origin & $\begin{array}{c}\text { Bot-BtF1 - Bot- } \\
\text { BtR1 amplification }\end{array}$ \\
\hline Botryosphaeria dothidea & BMV14 & DAR79239a & (Pitt et al. 2010) & Australia & + \\
\hline B. dothidea & TS18 & DAR79243 & (Pitt et al. 2010) & Australia & + \\
\hline B. dothidea & GE14 & DAR79241 ${ }^{\mathrm{a}}$ & (Pitt et al. 2010) & Australia & + \\
\hline B. dothidea & TS16 & DAR79242a & (Pitt et al. 2010) & Australia & + \\
\hline B. dothidea & PARC32 & & (Úrbez-Torres and O'Gorman 2016) & Canada & + \\
\hline B. dothidea & PARC78 & & (Úrbez-Torres and O’Gorman 2016) & Canada & + \\
\hline Diplodia mutila & CG15 & DAR79135 & (Pitt et al. 2010) & Australia & + \\
\hline D. mutila & CV5 & DAR79129a & (Pitt et al. 2010) & Australia & + \\
\hline D. mutila & D07 & DAR79136 & (Pitt et al. 2010) & Australia & + \\
\hline D. mutila & TS23 & DAR79001 ${ }^{\mathrm{a}}$ & (Pitt et al. 2010) & Australia & + \\
\hline D. mutila & FF18 & DAR79137 & (Pitt et al. 2010) & Australia & + \\
\hline D. mutila & PARC167 & & (Úrbez-Torres and O’Gorman 2016) & Canada & + \\
\hline D. mutila & PARC370 & & (Úrbez-Torres and O’Gorman 2016) & Canada & + \\
\hline Diplodia seriata & ME21 & DAR79237 & (Pitt et al. 2010) & Australia & + \\
\hline D. seriata & A142a & DAR79990a & (Qiu et al. 2011) & Australia & + \\
\hline D. seriata & $\mathrm{C} 54 \mathrm{a}$ & DAR79996 & (Qiu et al. 2011) & Australia & + \\
\hline D. seriata & D15a & DAR79991 ${ }^{\mathrm{a}}$ & (Qiu et al. 2011) & Australia & + \\
\hline D. seriata & $\mathrm{F} 142 \mathrm{~b}$ & DAR79992a & (Qiu et al. 2011) & Australia & + \\
\hline D. seriata & $\mathrm{F} 433 \mathrm{~b}$ & DAR79999a & (Qiu et al. 2011) & Australia & + \\
\hline D. seriata & $\mathrm{H} 223 \mathrm{c}$ & DAR $80000^{\mathrm{a}}$ & (Qiu et al. 2011) & Australia & + \\
\hline D. seriata & $\mathrm{K} 32 \mathrm{~b}$ & DAR79993 ${ }^{\mathrm{a}}$ & (Qiu et al. 2011) & Australia & + \\
\hline D. seriata & TWB1 & & $\mathrm{NWGIC}^{\mathrm{b}}$ & Australia & + \\
\hline D. seriata & TWB2 & & NWGIC & Australia & + \\
\hline D. seriata & TWB3 & & NWGIC & Australia & + \\
\hline D. seriata & TWB5 & & NWGIC & Australia & + \\
\hline D. seriata & PARC84 & & (Úrbez-Torres and O'Gorman 2016) & Canada & + \\
\hline D. seriata & PARC90 & & (Úrbez-Torres and O’Gorman 2016) & Canada & + \\
\hline Dothiorella vidmadera & M21 & DAR78994 $^{\mathrm{a}}$ & (Pitt et al. 2013) & Australia & + \\
\hline Do. vidmadera & L5 & DAR78993 $^{\mathrm{a}}$ & (Pitt et al. 2013) & Australia & + \\
\hline Do. vidmadera & $\mathrm{J} 4$ & DAR78992a & (Pitt et al. 2013) & Australia & + \\
\hline Lasiodiplodia theobromae & G31a & DAR77824 ${ }^{\mathrm{a}}$ & (Qiu et al. 2011) & Australia & + \\
\hline L. theobromae & $\mathrm{C} 2$ & DAR79507a & (Pitt et al. 2010) & Australia & + \\
\hline L. theobromae & W200 & DAR81024 ${ }^{\mathrm{a}}$ & (Wunderlich et al. 2011) & Australia & + \\
\hline Neofusicoccum australe & DNW8 & DAR79501 ${ }^{\mathrm{a}}$ & (Pitt et al. 2010) & Australia & + \\
\hline N. australe & FF10 & DAR79502 ${ }^{\mathrm{a}}$ & (Pitt et al. 2010) & Australia & + \\
\hline N. australe & SDW4 & DAR79505 ${ }^{\mathrm{a}}$ & (Pitt et al. 2010) & Australia & + \\
\hline N. australe & VP13 & DAR79506 & (Pitt et al. 2010) & Australia & + \\
\hline N. australe & BB59-3 & DAR81004 $^{\mathrm{a}}$ & (Wunderlich et al. 2011) & Australia & + \\
\hline Neofusiccocum luteum & H12-1 & DAR80983a & (Wunderlich et al. 2011) & Australia & + \\
\hline N. luteum & HH119-1 & DAR81013 ${ }^{a}$ & (Wunderlich et al. 2011) & Australia & + \\
\hline N. luteum & BB175-2 & DAR81016 & (Wunderlich et al. 2011) & Australia & + \\
\hline N. luteum & НH197-1 & DAR81018 & (Wunderlich et al. 2011) & Australia & + \\
\hline N. luteum & FF23-1 & DAR81019a & (Wunderlich et al. 2011) & Australia & + \\
\hline N. luteum & $\mathrm{C} 17$ & CBS110299c & (Úrbez-Torres and O’Gorman 2016) & Portugal & + \\
\hline Neofusicoccum parvum & B19A & DAR78998 a & (Pitt et al. 2010) & Australia & + \\
\hline N. parvum & B $44 \mathrm{a}$ & DAR80005 ${ }^{\mathrm{a}}$ & (Qiu et al. 2011) & Australia & + \\
\hline N. parvum & $\mathrm{B} 22 \mathrm{a}$ & DAR80004 $^{\mathrm{a}}$ & (Qiu et al. 2011) & Australia & + \\
\hline N. parvum & E12a & DAR77823a & (Qiu et al. 2011) & Australia & + \\
\hline N. parvum & F321b & DAR80008 & (Qiu et al. 2011) & Australia & + \\
\hline N. parvum & TWB6 & & NWGIC & Australia & + \\
\hline N. parvum & TWB7 & & NWGIC & Australia & + \\
\hline N. parvum & PARC37 & & (Úrbez-Torres and O’Gorman 2016) & Canada & + \\
\hline Neofusicoccum ribis & CBS $115475^{\mathrm{c}}$ & CBS $115475^{\mathrm{c}}$ & (Úrbez-Torres and O’Gorman 2016) & U.S.A. & + \\
\hline Spencermartinsia viticola & M11 & DAR78868 & (Pitt et al. 2010) & Australia & + \\
\hline S. viticola & $\mathrm{J} 8$ & DAR78867 & (Pitt et al. 2010) & Australia & + \\
\hline S. viticola & L19 & DAR78870 & (Pitt et al. 2010) & Australia & + \\
\hline S. viticola & $\mathrm{J} 7$ & DAR78869a & (Pitt et al. 2010) & Australia & + \\
\hline S. viticola & $\mathrm{C} 5$ & CBS $117009^{c}$ & (Úrbez-Torres and O’Gorman 2016) & Spain & + \\
\hline
\end{tabular}

a Agricultural Scientific Collections Unit, NSW DPI, Orange, Australia.

${ }^{b}$ NWGIC: National Wine and Grape Industry, Charles Sturt University, Wagga Wagga, NSW, Australia.

${ }^{\mathrm{c}}$ CBS: Ex-type specimens purchased by SuRDC, Canada, from CBS-KNAW Culture Collection, The Netherlands. 
SYBR Green Supermix (BIO-RAD, Pty. Ltd., U.S.A.), $500 \mathrm{~nm}$ of each primer, $2 \mu \mathrm{l}$ template, and nuclease-free water (Qiagen, U.S.A.). All qPCR were performed using four replicates in three independent assays using the following thermal cycling conditions: $3 \mathrm{~min}$ at $98^{\circ} \mathrm{C}$, followed by 35 cycles of $98^{\circ} \mathrm{C}$ for $30 \mathrm{~s}, 60^{\circ} \mathrm{C}$ for $30 \mathrm{~s}$, and fluorescence detection at $60^{\circ} \mathrm{C}$ for $15 \mathrm{~s}$. After the final amplification cycle, a dissociation (melting) curve $\left(72\right.$ to $95^{\circ} \mathrm{C}$ ) was generated to check the specificity of the amplification reaction.

Hydrolysis (TaqMan) qPCR. The qPCR multispecies primers were further performed using Hydrolysis (TaqMan) qPCR. Each $20 \mu \mathrm{l}$ reaction contained $10 \mu \mathrm{l}$ of $2 \times$ GoTaq Master Mix (Promega, U.S.A.), $500 \mathrm{~nm}$ of each primer, $250 \mathrm{~nm}$ of Taq-Bot probe (Fig. 1), and $7 \mu 1$ of template DNA. The Taq-Bot probe was labeled at the $5^{\prime}$ end with 6-carboxyfluorescein (FAM) and a double-quencher (internal Zen with 3' Iowa Black FQ; Integrated DNA Technologies, U.S.A.). The qPCR conditions were set up using the optimal annealing temperature and primer concentration determined previously. All reactions were conducted using the following thermal cycling conditions: $2 \mathrm{~min}$ at $98^{\circ} \mathrm{C}$, followed by 40 cycles of $98^{\circ} \mathrm{C}$ for $10 \mathrm{~s}, 60^{\circ} \mathrm{C}$ for $30 \mathrm{~s}$, and fluorescence detection at $60^{\circ} \mathrm{C}$ for $30 \mathrm{~s}$. For each assay, three controls were included: a) non-template control $\left(\mathrm{NTC}, \mathrm{H}_{2} \mathrm{O}\right)$; b) positive control $(D$. seriata gDNA, $2 \mathrm{ng}$ ); and c) negative control (E. lata gDNA, $2 \mathrm{ng})$.

Construction of standard curve. To generate the standard curve necessary for the quantification of Botryosphaeriaceae inocula, the 51 reference sequences for Botryosphaeriaceae species were further aligned by ClustalW using MEGA7 (Kumar et al. 2016) to design a chemically synthesized single copy of the $\beta$-tubulin gene. The 410-bp Bot-Btub gBlocks Gene Fragments (Integrated DNA Technologies, U.S.A.; Fig. 1) was based on the internal fragment of the $\beta$-tubulin gene, and the annealing sites for Bot-BtF1 and Bot-BtR1 primers are on the 215235 and 365-385 bp of the fragment, respectively. The $500 \mathrm{ng}$ lyophilized Bot-Btub gBlocks was resuspended in $50 \mu \mathrm{l}$ of TE Buffer (Tris

Table 2. Fungal isolates of nontarget species used for testing the specificity of Botryosphaeriaceae multispecies primers Bot-BtF1 and Bot-BtR1 by conventional PCR

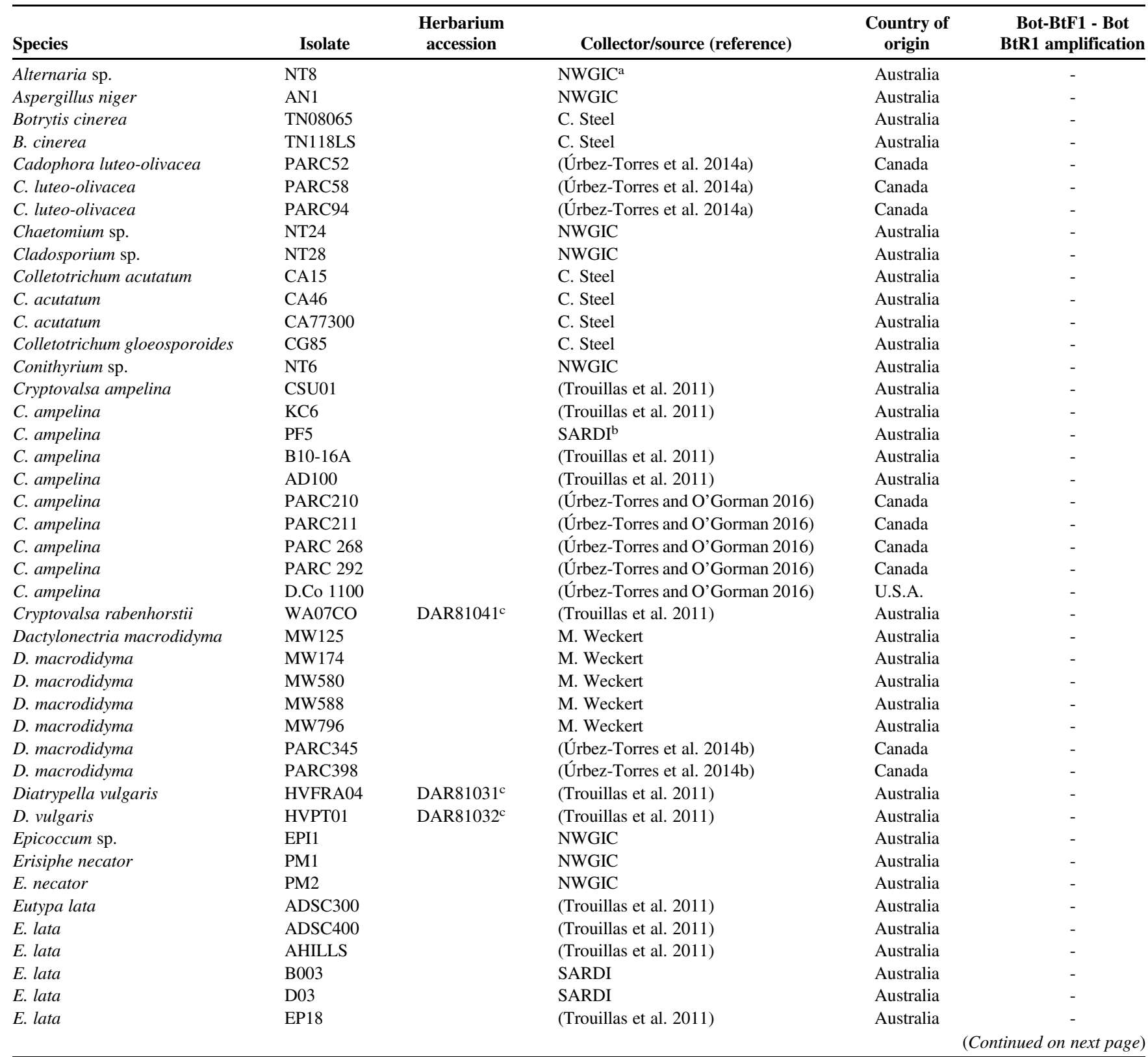

${ }^{a}$ NWGIC - National Wine and Grape Industry, Charles Sturt University, Wagga Wagga, NSW, Australia.

b SARDI - South Australian Research and Development Institute, Australia.

${ }^{c}$ DAR - Agricultural Scientific Collections Unit, NSW DPI, Orange, Australia.

d VPRI National Collection of Fungi, Victoria, Australia. 
and EDTA, pH 8.0; Sigma Aldrich, U.S.A.) following the manufacturer's recommendation, to reach a final concentration of $10 \mathrm{ng} / \mu \mathrm{l}$.

The total copy number of the Bot-Btub gBlocks was calculated following the formula (Lee et al. 2006, 2016): No. of copies $=(6.02 \times$ $10^{23}[\mathrm{copy} / \mathrm{mol}] \times$ DNA amount $\left.[\mathrm{g}]\right) /($ DNA length $[\mathrm{dp}] \times 660$ $[\mathrm{g} / \mathrm{mol} / \mathrm{dp}])$. The $10 \mathrm{ng} / \mu \mathrm{l}$ stock solution of Bot-Btub gBlocks was calculated at $2.2 \times 10^{9}$. To prepare the standards, a 10 -fold dilution from $2.2 \times 10^{6}$ to 2.2 copies was further prepared and used to develop a standard curve using the qPCR conditions described below. Each $20 \mu \mathrm{l}$ reaction contained $10 \mu \mathrm{l}$ of $2 \times$ GoTaq Master Mix (Promega, U.S.A.), $500 \mathrm{~nm}$ of each primer, $250 \mathrm{~nm}$ of Taq-Bot probe, and $7 \mu \mathrm{l}$ of each standard solution $\left(15 \times 10^{1}\right.$ to $15 \times 10^{6}$ copies per reaction). The qPCR conditions were set up using the optimal annealing temperature and primer concentration determined previously. All qPCR reactions were conducted using the following thermal cycling conditions: $2 \mathrm{~min}$ at $98^{\circ} \mathrm{C}$, followed by 40 cycles of $98^{\circ} \mathrm{C}$ for $10 \mathrm{~s}, 60^{\circ} \mathrm{C}$ for $30 \mathrm{~s}$, and fluorescence detection at $60^{\circ} \mathrm{C}$ for $30 \mathrm{~s}$. For each assay, three controls were included: a) non-template control (NTC, $\left.\mathrm{H}_{2} \mathrm{O}\right)$; b) positive control (D. seriata gDNA); and c) negative control (E. lata gDNA).

The quantification cycle $(\mathrm{Cq})$ value for each Bot-Btub gBlocks standard sample was calculated and analyzed using the Rotor-Gene Q Series software (Version 2.3.1) to generate a standard curve. The number of copies for each Bot-Btub gBlocks standard dilution was plotted against the $\mathrm{Cq}$ values and the resulting regression equations were used to quantify the number of copies of each target gene in the unknown samples.

The limit of detection (LOD) and sensitivity of the qPCR developed was determined using Bot-Btub gBlock standards and genomic DNA as templates. The following gDNA concentrations were used as templates: a) D. seriata (DAR79990) $5.25 \times 10^{7}, 5.25 \times 10^{6}$, $5.25 \times 10^{5}, 5.25 \times 10^{4}, 5.25 \times 10^{3}, 875,525,300,52.5$, and 5.25 fg/reaction; b) $N$. parvum (DAR78998), $2 \times 10^{7}, 2 \times 10^{6}, 2 \times 10^{5}$, $2 \times 10^{4}, 2 \times 10^{3}, 1 \times 10^{3}, 2 \times 10^{2}$, and $2 \times 10^{1} \mathrm{fg} / \mathrm{reaction}$. These gDNA samples were analyzed by qPCR with Bot-Btub gBlocks as

Table 2. (Continued from previous page)

\begin{tabular}{|c|c|c|c|c|c|}
\hline Species & Isolate & $\begin{array}{c}\text { Herbarium } \\
\text { accession }\end{array}$ & Collector/source (reference) & $\begin{array}{l}\text { Country of } \\
\text { origin }\end{array}$ & $\begin{array}{c}\text { Bot-BtF1 - Bot } \\
\text { BtR1 amplification }\end{array}$ \\
\hline E. lata & SACEA01 & & SARDI & Australia & - \\
\hline E. lata & WB052 & & SARDI & Australia & - \\
\hline E. lata & OR039 & & SARDI & Australia & - \\
\hline E. lata & PARC303 & & (Úrbez-Torres and O’Gorman 2016) & Canada & - \\
\hline E. lata & PARC381 & & (Úrbez-Torres and O’Gorman 2016) & Canada & - \\
\hline Eutypa leptoplaca & ADFIC100 & & (Trouillas et al. 2011) & Australia & - \\
\hline E. leptoplaca & RGA02 & & (Trouillas et al. 2011) & Australia & - \\
\hline E. leptoplaca & TUPNO2 & & (Trouillas et al. 2011) & Australia & - \\
\hline E. leptoplaca & TUQU01 & & (Trouillas et al. 2011) & Australia & - \\
\hline E. leptoplaca & SAPN04 & & (Trouillas et al. 2011) & Australia & - \\
\hline E. leptoplaca & ABA200 & & (Trouillas et al. 2011) & Australia & - \\
\hline E. leptoplaca & ADSC500 & & (Trouillas et al. 2011) & Australia & - \\
\hline Eutypella citricola & T3R2S2 & & (Trouillas et al. 2011) & Australia & - \\
\hline E. citricola & WA06FH & & (Trouillas et al. 2011) & Australia & - \\
\hline E. citricola & TWD1 & & NWGIC & Australia & - \\
\hline E. citricola & TWD2 & & NWGIC & Australia & - \\
\hline E. citricola & TWD3 & & NWGIC & Australia & - \\
\hline Eutypella cryptovalsoidea & HVFIG02 & DAR81038c & (Trouillas et al. 2011) & Australia & - \\
\hline Eutypella microtheca & HVGRF02 & DAR81039c & (Trouillas et al. 2011) & Australia & - \\
\hline E. microtheca & HVVIT05 & DAR81040 & (Trouillas et al. 2011) & Australia & - \\
\hline Greneria uvicola & GR15 & & (Rathnayake et al. 2018) & Australia & - \\
\hline G. uvicola & GR35 & & (Rathnayake et al. 2018) & Australia & - \\
\hline Fusarium sp. & MW887 & & M. Weckert & Australia & - \\
\hline Fusarium sp. & NT13 & & NWGIC & Australia & - \\
\hline llyonectria liriodendri & MW65 & & M. Weckert & Australia & - \\
\hline I. liriodendri & MW122 & & M. Weckert & Australia & - \\
\hline I. liriodendri & PARC60 & & (Úrbez-Torres et al. 2014b) & Canada & - \\
\hline I. liriodendri & PARC72 & & (Úrbez-Torres et al. 2014b) & Canada & - \\
\hline Penicillium spp. & PN1 & & NWGIC & Australia & - \\
\hline Phaeoacremonium minimum & MA036 & & SARDI & Australia & - \\
\hline P. minimum & MA048 & & SARDI & Australia & - \\
\hline P. minimum & MA056 & & SARDI & Australia & - \\
\hline P. minimum & PARC158 & & (Úrbez-Torres et al. 2014a) & Canada & - \\
\hline P. minimum & PARC172 & & (Úrbez-Torres et al. 2014a) & Canada & - \\
\hline P. minimum & PARC187 & & (Úrbez-Torres et al. 2014a) & Canada & - \\
\hline $\begin{array}{l}\text { Phaeomoniella } \\
\text { chlamydospora }\end{array}$ & WB007 & & SARDI & Australia & - \\
\hline P. chlamydospora & MA006 & & SARDI & Australia & - \\
\hline P. chlamydospora & $\mathrm{V} 21351 \mathrm{a}^{\mathrm{d}}$ & $\mathrm{V} 21351 \mathrm{a}^{\mathrm{d}}$ & G. Marchi & Australia & - \\
\hline P. chlamydospora & $\mathrm{V} 22912^{\mathrm{d}}$ & $V 22912^{d}$ & I.G. Pascoe & Australia & - \\
\hline P. chlamydospora & PARC13 & & (Úrbez-Torres et al. 2014a) & Canada & - \\
\hline P. chlamydospora & PARC50 & & (Úrbez-Torres et al. 2014a) & Canada & - \\
\hline Phomopsis viticola & VRU006 & & C. Steel & Australia & - \\
\hline P. viticola & VRU0076 & & C. Steel & Australia & - \\
\hline P. viticola & $\mathrm{CB} 4-2$ & & C. Steel & Australia & - \\
\hline P. viticola & CB4-4 & & C. Steel & Australia & - \\
\hline P. viticola & PARC85 & & (Úrbez-Torres and O’Gorman 2016) & Canada & - \\
\hline P. viticola & PARC113 & & (Úrbez-Torres and O’Gorman 2016) & Canada & - \\
\hline
\end{tabular}


standards using four replicates in three independent assays following the conditions previously described. In addition to the standard 10-fold dilutions, lower concentrations of the Bot-Btub gBlock (3 and 7 copies/reaction) were also included in the qPCR analyses using four replicates in three independent assays. The LOD was determined following the MIQE guidelines (Bustin et al. 2009), which was based on the number of copies required to obtain reproducible detection in three consecutive assays.

The number of copies of the target $\beta$-tubulin gene in a haploid genome of Botryosphaeriaceae was determined using each gDNA dilution of D. seriata (DAR79990) and N. parvum (DAR78998) previously prepared and analyzed by qPCR with Bot-Btub gBlocks as standards. Using the size of the haploid genome of $D$. seriata (37.1 $\mathrm{mbp}$ ) and $N$. parvum (42.6 mbp) (Morales-Cruz et al. 2015), the mass of each genome is estimated to be 39 and $45 \mathrm{fg}$, respectively. The quantification of the number copies of $\beta$-tubulin gene per ng of DNA was achieved by comparing the $\mathrm{Cq}$ values to each gDNA concentrations with the $\mathrm{Cq}$ values of the Bot-Btub gBlocks standards.

The specificity of the primers was tested by qPCR using $\sim 3 \mathrm{ng}$ of gDNA of four Diatrypaceae species: Cryptovalsa ampelina (CSU01), Eutypella citricola (DAR81035), E. lata (ADSC-300), and E. leptoplaca (RGA02). The qPCR was run using four replicates and repeated twice using the protocol described previously with Bot-Btub gBlock $\left(15 \times 10^{6}\right)$ as a standard; $\mathrm{H}_{2} \mathrm{O}$ for NTC, and D. seriata gDNA (DAR79990, 1 ng) as a positive control. To test the effect of nontarget DNA on the sensitivity and specificity of the method, qPCR was performed by comparing the quantification of $5 \mathrm{ng}$ of D. seriata gDNA (DAR79990) alone and when the same DNA was spiked with $1.5 \mathrm{ng}$ of either E. lata (ADSC-300) or C. ampelina (CSU01). The assay was performed using four replicates and repeated twice. The data were statistically analyzed by ANOVA and pairwise comparison by LSD using SPSS Statistics 20.

DNA extraction from artificially-inoculated spore tapes. Two published DNA extraction protocols (Duvivier et al. 2013; Rogers et al. 2009) and two commercial DNA extraction kits (PowerWater DNA Isolation Kit, MoBio Laboratories, U.S.A.; Gentra Puregene, Qiagen, U.S.A.) were tested for their suitability to extract DNA from spore tapes. Preliminary tests were conducted for each protocol using the spore tapes artificially inoculated with $N$. luteum conidia. Three $N$. luteum isolates (DAR80983, DAR81013, DAR81016) that were stored as mycelial plugs in sterile water were subcultured onto fresh PDA amended with chloramphenicol (PDAC, $100 \mathrm{mg} /$ liter of agar). The cultures were incubated at $25^{\circ} \mathrm{C}$ overnight in total darkness before being transferred to UV light in a $12 \mathrm{~h}$ light-dark regime for 4 to 5 weeks $\left(18\right.$ to $\left.22^{\circ} \mathrm{C}\right)$ until pycnidia developed. To harvest the conidia, pycnidia were scraped from the agar with a sterile spatula and ground in a sterile mortar and pestle with $\sim 5 \mathrm{ml}$ sterile water before sieving using two layers of sterile Miracloth (Merck Darmstadt, Germany). The conidia recovered from each of the three isolates were combined and concentrations were determined and adjusted accordingly using a hemocytometer (Labor Optik, U.K.).

Melinex tapes $(2 \times 33 \mathrm{~cm}$, Burkard Scientific, U.K.) were mounted onto a spore drum (Burkard Scientific, U.K.), attached to a laboratory stand bracket, and coated with a petroleum-based adhesive, Tangle-

TGCCGCGCCCCCCGCTGACGCCAATCGACACCACAGGCAGACTATCTCTGGCGAGCACGGCCTGG ACGGCTCCGGCGTGTAAGTTTGCGCTGTCTTTGCCGCGCTCTGCAATCGCTGACCCTTGGCAGCT

ACAATGGCACCTCCGACCTCCAGCTGGAGCGCATGAACGTCTACTTCAACGAGGTACTCTCTACT Bot-BtF 1

AGTTAGACAAACACGTAAAGTATGGCAATCTTCTGAACGCGCAGCAGGCATCCAACAATAAGTAC Taq-Bot probe

GTTCCTCGTGCTGTCCTCGTTGACCtcgagCCCggcaccatggatGCCGTCCGCGCCGGCCCCTT

CGGCCAGCTCTTCCGTCCCGACAACTTCGTTTTCGGCCAGTCTGGTGCCGGTAACAACTGGGCCA

AGGGTCACTACACTGAGGGT

Fig. 1. DNA sequences for the Bot-Btub gBlocks gene fragment used for the construction of the quantitative PCR standard curve. The primers binding sites are shown underlined in bold letters and the probe binding site is shown underlined in lower case.
Trap (The Tanglefoot Company, U.S.A.), using a paintbrush. For processing, the tapes were removed from the drum using fine-point forceps and cut into $(1 \times 1.9 \mathrm{~cm})$ sections on a perspex cutting block (Eglinton Engineering, Magill, South Australia) using a sterile scalpel. Spore tapes were mounted onto a microscope slide using double sided tape prior to inoculations. Each tape section was inoculated with $20 \mu$ l suspensions of 3,000 conidia of $N$. luteum by dotting 20 to 30 droplets onto the tape using a sterile pipette. Inoculated tapes were allowed to dry inside the biohazard cabinet for $30 \mathrm{~min}$ and transferred into a sterile $2 \mathrm{ml}$ Eppendorf tube and stored at $-20^{\circ} \mathrm{C}$ until DNA extractions. DNA extractions were performed following the different protocols using six replicate tapes per extraction. To determine the efficiency of each protocol, $1 \mu$ l of each sample was used as template for standard and nested PCR. For standard PCR, Bot100F and Bot472R primers were used following the protocol and thermal cycling conditions as previously described (Ridgway et al. 2011). The nested PCR was performed by initially amplifying $1 \mu \mathrm{l}$ of the DNA extract using the universal primer ITS1-F and ITS4 (White et al. 1990). The second step PCR was conducted by running $1 \mu \mathrm{l}$ of the Step 1 PCR products as a template using the primers Bot $100 \mathrm{~F}$ and Bot $472 \mathrm{R}$ and the protocol previously described (Ridgway et al. 2011). All PCR products were visualized by gel electrophoresis following the protocol described previously.

The extraction method based on the Gentra Puregene (Qiagen, U.S.A.) protocol with numerous adaptations gave consistent DNA yield in the preliminary test. This protocol, which is described in detail below, was further tested using spore tapes inoculated with different concentrations of $N$. luteum conidia. Spore tapes coated with Tangle Trap were cut into individual $1.9-\mathrm{cm}$ sections and inoculated with $20-\mu$ l suspensions containing either $100,000,10,000,1,000$, or 100 conidia as described previously. All inoculated tapes were stored at $-20^{\circ} \mathrm{C}$ until DNA extractions. The frozen tapes were transferred into sterile 2-ml Eppendorf tubes (lysing tube) containing $\sim 300 \mathrm{mg}$ of (400 to $600 \mu \mathrm{m}$ diameter) Ballatoni beads (Daintree Scientific, Australia) and one 1/4" ceramic sphere (MP Biomedicals, U.S.A.) and used for DNA extractions at four replicate tapes per concentration. To extract DNA, $500 \mu \mathrm{l}$ of Cell Lysis solution (Gentra Puregene, Qiagen, U.S.A.) and $10 \mu \mathrm{l}$ of Proteinase K (Promega, U.S.A.) were added to a lysing tube containing the inoculated tape sections. The tubes were placed into the TissueLyser (Qiagen, U.S.A.) microtube adapter and shaken twice for $90 \mathrm{~s}$ at $30 \mathrm{~Hz}$ with $1 \mathrm{~min}$ cooling on ice between each shake. The samples were incubated at $55^{\circ} \mathrm{C}$ overnight in a water bath. After incubation, $1.5 \mu \mathrm{l}$ of RNAse A ( $4 \mathrm{mg} / \mathrm{ml}$, Qiagen, U.S.A.) was added and incubated at $37^{\circ} \mathrm{C}$ for $30 \mathrm{~min}$. The tubes were cooled at room temperature and $167 \mu \mathrm{l}$ of protein precipitation solution (Gentra Puregene, Qiagen, U.S.A.) was added to the cell lysate and mixed by vortexing at high speed for $20 \mathrm{~s}$ and placed on ice for $5 \mathrm{~min}$. The mixture was centrifuged at $16,000 \times g$ for $3 \mathrm{~min}$ and the supernatant $(\sim 650 \mu \mathrm{l})$ was transferred to a new sterile $1.5-\mathrm{ml}$ tube. The DNA was precipitated by adding $500 \mu \mathrm{l}$ of ice-cold isopropanol and $1 \mu \mathrm{l}$ of glycogen (Qiagen, U.S.A.) to the supernatant, inverted 30 to 50 times, and centrifuged at $16,000 \times g$ for $5 \mathrm{~min}$. The supernatant was discarded and dabbed dry onto clean absorbent paper. The DNA pellet was washed by adding $300 \mu \mathrm{l}$ of ice-cold $70 \%$ ethanol and the tube was inverted gently ( $\sim 10$ times) and centrifuged for $1 \mathrm{~min}$ at $16,000 \times g$. The ethanol was decanted gently and the tube containing the DNA pellet was air dried for 1 to $2 \mathrm{~h}$ at room temperature. Finally, the DNA was resuspended by adding $30 \mu \mathrm{l}$ of nuclease-free water (Qiagen, U.S.A.) and stored at $-20^{\circ} \mathrm{C}$ until required for PCR.

To determine the efficiency of the protocol, standard and nested PCR using Bot100F and Bot472R primers were performed using $1 \mu \mathrm{l}$ of each sample following the protocol previously described, and the PCR products were visualized by gel electrophoresis as previously described. The efficiency of the DNA extraction protocol was further tested by performing qPCR using the Bot-BtF1 and Bot-BtR1 multispecies primers and $2 \mu \mathrm{l}$ of each DNA sample as template.

Quantitative PCR of vineyard spore trap samples. For spore trapping, two volumetric spore traps (Burkard Scientific, U.K.) fitted with battery and solar panel for recharging (Measurement Engineering, Australia) were deployed in the Hunter Valley and Griffith 
(NSW) from June 2014 to May 2015. In the Hunter Valley, the spore trap was placed at the end of a vine row, while in Griffith the spore trap was placed approximately $10 \mathrm{~m}$ from the vines. Melinex tapes $(2 \times 33 \mathrm{~cm}$, Burkard Scientific, U.K.) were mounted onto spore drums in the laboratory as previously described. The drums were placed inside the spore trap chambers with the clocks set for 36 days. Both spore traps were operated with the orifice $0.5 \mathrm{~m}$ above the ground with an airflow of 10 liters/min. Spore drums were collected and replaced every 4 weeks. For processing, the tapes were excised from the drum and cut longitudinally into two sections through a perspex cutting block (Eglinton Engineering, Magill, Australia) using a sterile scalpel. One section was further cut into 2-day sections $(1 \times$ $1.9 \mathrm{~cm}$ ) using the 36-day rotation cutting block (Eglinton Engineering, Magill, Australia). The remaining section was stored in a section of electrical conduit at $-20^{\circ} \mathrm{C}$ as a backup. Each tape section was placed in a lysing tube as described previously and stored at room temperature until DNA extractions. DNA was extracted from all samples using the modified Gentra Puregene (Qiagen, U.S.A.) protocol described previously. To check for any variations in each batch of DNA extractions, three control tapes $(1.9 \times 1 \mathrm{~cm})$ were included in each batch ( 45 samples). These were: 1$)$ tape inoculated with $N$. luteum conidia (positive control); 2) noninoculated tape (nontemplate control); and 3) tape inoculated with E. lata ascospores (negative control). Each control tape was placed inside a 2-ml lysing tube as previously described and one tube each of the control tapes was included in each batch of DNA extraction.

All DNA extracted from spore trap samples (377 samples, 2-day sections) from the Hunter Valley and Griffith were initially tested for the presence or absence of Botryosphaeriaceae DNA by nested PCR. The nested PCR was performed by initially amplifying $2 \mu \mathrm{l}$ of spore tape DNA extracts using the universal primer ITS1-F and ITS-4 (White et al. 1990) with the annealing temperature of $55^{\circ} \mathrm{C}$ at 25 cycles. The second step PCR was conducted by running $1 \mu \mathrm{l}$ of the Step 1 PCR products as a template using the primers Bot100F and Bot472R and the protocol previously described (Ridgway et al.

Table 3. Quantitative PCR of DNA extracted from spore tapes inoculated with different concentrations of Neofusicoccum luteum conidia using the modified Gentra Puregene DNA extraction protocol

\begin{tabular}{lcc}
\hline No. of conidia/tape & $\begin{array}{c}\text { Calculated no. of } \\
\text { conidia/reaction }\end{array}$ & $\begin{array}{c}\text { Mean } \mathbf{C q}^{\mathbf{a}} \\
\text { values } \pm \text { std dev }\end{array}$ \\
\hline 100,000 & 6,667 & $20.75 \pm 0.11$ \\
10,000 & 667 & $24.10 \pm 0.04$ \\
1,000 & 67 & $26.23 \pm 0.29$ \\
100 & 6.7 & $30.82 \pm 0.38$ \\
\hline
\end{tabular}

a The mean $\mathrm{Cq}$ values were based on four technical replicates per concentration.
2011). For each nested PCR, four controls were included: a) NTC1 $\left(\mathrm{H}_{2} \mathrm{O}\right)$; b) NTC2 (noninoculated spore tape); c) positive control ( N. luteum conidia inoculated tape); and d) negative control (E. lata ascospore inoculated tape). PCR products from the second step of each nested PCR were visualized by electrophoresis following the protocol as previously described.

Samples positive to nested PCR were further analyzed by qPCR to determine the number of spores trapped in each 2-day period. Each qPCR was performed following the qPCR protocols described previously and the following controls and standards were included: a) BotBtub gBlock standard solutions $\left(1.5 \times 10^{7}\right)$; b) NTC1 $\left(\mathrm{H}_{2} \mathrm{O}\right)$; c) NTC2 (noninoculated tape); d) positive control (N. luteum inoculated tape); e) negative control (E. lata inoculated tapes). All samples were run in duplicate except for the NTC and gBlock standards, which were run in four replicates. To analyze samples for each qPCR, the standard curves previously developed were imported in the RotorGene Q software. The standard (Bot-Btub $1.5 \times 10^{7} \mathrm{gBlocks}$ ) that was included in each qPCR was used to calibrate the imported standard curve. The mean $\mathrm{Cq}$ values for each unknown sample were plotted against the $\mathrm{Cq}$ values of the standards and the resulting regression equations were used to quantify the number of conidia in each sample as previously described.

Data analyses. To calculate the number of Botryosphaeriaceae spores in 2-day spore tape samples, the following formula was used:

$$
N=Q(D / T)(2)
$$

Where $N=$ calculated no. of spores in a 2-day period, $Q=$ the mean number of spores detected by qPCR, $D=$ total DNA volume $(30 \mu \mathrm{l})$ extracted from a $1 / 2$ section of a 2-day sample, $T=$ the amount of DNA template $(7 \mu \mathrm{l} /$ reaction $)$ used in one reaction, and $2=$ the total number of tape sections for the 2-day collection period.

\section{Results}

Primer development. The design of the multispecies primers for the Botryosphaeriaceae species was based on the alignment of the $\beta$-tubulin gene sequences. No binding sites suitable for qPCR multispecies primers were identified when the ITS region for all 10 Botryosphaeriaceae spp. were aligned. The primers BotBtF1 (5'-GTATGGCAATCTTCTGAACG-3') and Bot-BtR1 (5'-CAGTTGTTACCGGCRCCAGA-3'), which was degenerate at nucleotide 15 , were designed to anneal to the $\beta$-tubulin gene region for all 10 target Botryosphaeriaceae species. Preliminary tests using conventional PCR showed the optimum annealing temperature for the Bot-BtF1 and Bot-BtR1 primers was $60^{\circ} \mathrm{C}$, which amplified a single 135-bp PCR product for all 10 Botryosphaeriaceae spp. tested (Table 1). No PCR products were observed with the DNA of the 27 other nontarget species from grapevines (Table 2) and the nontemplate controls. The standard PCR using serially diluted gDNA of

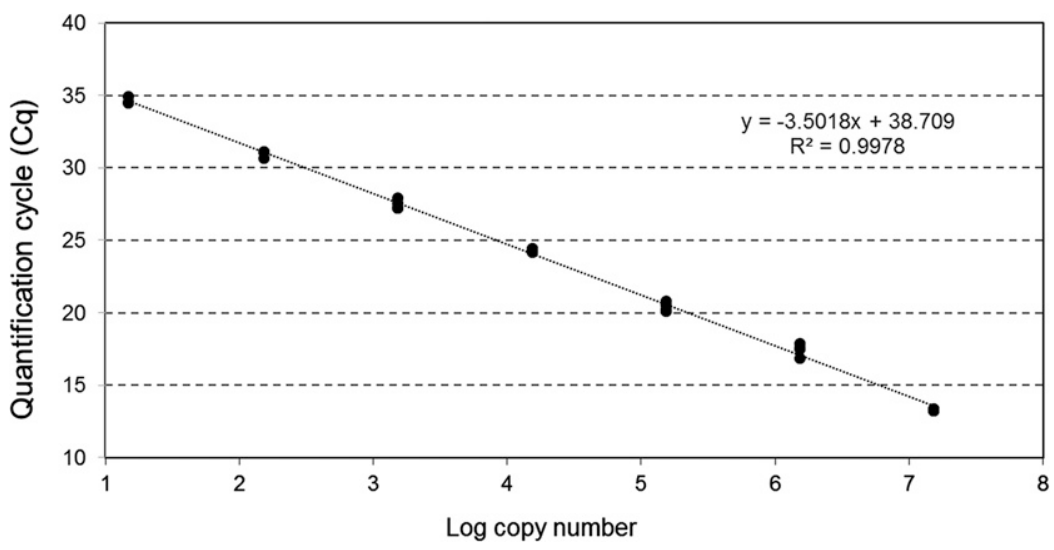

Fig. 2. Standard curve for quantitative PCR ( $q P C R$ ) using multispecies primers Bot-BtF1 and Bot-BtR1 to quantify Botryosphaeriaceae inoculum. The standard curves were constructed with 10-fold dilutions of the Bot-Btub gBlocks gene fragments ranging from $15 \times 10^{1}$ to $15 \times 10^{6}$ copies per reaction. Each standard dilution was amplified by qPCR using primers Bot-BtF1 and Bot-BtR1 and the hydrolysis probe Taq-Bot in four replicates. The efficiency was $94 \%$ and the linear regression of standard curves gave a coefficient of determination of $R^{2}=0.9978$. 
D. seriata (DAR79990) and N. parvum (DAR78998) demonstrated that the Bot-BtF1 and Bot-BtR1 multispecies primers could detect $\sim 100$ pg of gDNA while the nested PCR protocol was able to detect as low as $1 \mathrm{pg}$ of gDNA (data not shown).

Primer validation using international isolates. Validation of primers using the SuRDC isolate collection and equipment showed that all primers were able to amplify their corresponding target species while no PCR products were observed with any of the DNA from any nontarget species, further confirming the results of the specificity test conducted at CSU, Australia.

Efficiency of the DNA extraction protocols from spore tape samples. Of the four DNA extraction protocols tested, one published protocol (Duvivier et al. 2013) and the modified Gentra PureGene (Qiagen, U.S.A.) protocol gave consistent DNA yield while the other two protocols gave variable results (data not shown). Furthermore, the second published protocol tested (Rogers et al. 2009) required reagents not readily available in Australia while the first one (Duvivier et al. 2013) required hazardous chemicals including 2mercaptoethanol and phenol-chloroform that can only be safely handled in a fume hood. However, the Gentra Puregene (Qiagen, U.S.A.) protocol with major adaptations was found to be easy to use and did not require toxic chemicals compared with the other protocols. Efficiency tests showed that tape samples inoculated with 1,000 and 10,000 conidia of $N$. luteum using the modified Gentra Puregene (Qaigen, U.S.A.) protocol were amplified by standard PCR while tapes inoculated with 100 conidia were amplified by nested PCR (data not shown) and qPCR (Table 3). Since each nested PCR and qPCR reaction contained 1 and $2 \mu$ l template, respectively, from the $30 \mu \mathrm{l}$ total DNA extracted from the tape, the nested PCR was able to detect as low as three conidia while qPCR was able to detect up to seven conidia per reaction.

Development of qPCR using hydrolysis probe. The preliminary test using SYBR green qPCR showed the multispecies primers BotBtF1 and Bot-BtR1 produced PCR byproducts when the DNA templates were very low ( $<1 \mathrm{pg}$, data not shown). However, the Bot-Btub gBlock (Fig. 1) and the gDNA of D. seriata and N. parvum were successfully quantified by qPCR using the hydrolysis probe Taq-Bot (5'-/56-FAM/TCGAGCCCG/ZEN/GCACCATGGAT/3IBkFQ/-3'). Reaction efficiencies of 94 to $99 \%$ with coefficients of determination of $R^{2}=0.99$ were obtained based on the slopes of the standard curve for the Bot-Btub gBlock in three independent assays (Fig. 2). No amplifications were observed on NTC $\left(\mathrm{H}_{2} \mathrm{O}\right)$ and nontarget DNA (E. lata), indicating that the primers were specific only to the Botryosphaeriaceae DNA and did not amplify nontarget DNA.

The LOD of the qPCR was seven copies using the Bot-Btub gBlock standard while three copies of the gBlocks were not detected by the assay (Table 4). For gDNA, 300 and $200 \mathrm{fg}$ of $D$. seriata and N. parvum gDNA, respectively, were detected by the assay while no amplifications were observed using 50,20, and $5 \mathrm{fg}$ of gDNA (Table 5). The qPCR results further showed the mean number of

Table 4. Determination of the limit of detection (LOD) of the qPCR using different concentrations of Bot-Btub gBlocks

\begin{tabular}{lcc}
\hline Copies/reaction & Cq values $^{\mathbf{a}}$ & Signal ratio $^{\mathbf{b}}$ \\
\hline $15,000,000$ & $12.32 \pm 0.02$ & $12 / 12$ \\
$1,500,000$ & $16.22 \pm 0.07$ & $12 / 12$ \\
150,000 & $19.56 \pm 0.12$ & $12 / 12$ \\
15,000 & $22.95 \pm 0.11$ & $12 / 12$ \\
1,500 & $26.44 \pm 0.06$ & $12 / 12$ \\
150 & $30.21 \pm 0.32$ & $12 / 12$ \\
15 & $33.40 \pm 0.95$ & $12 / 12$ \\
7 & $34.89 \pm 1.17$ & $12 / 12$ \\
3 & No detection & $0 / 12$ \\
\hline${ }^{a}$ Quantification cycles $($ Cq) at which fluorescence was detected. The Cq val- \\
ues and corresponding standard errors $( \pm)$ were derived from the means of \\
three independent assays each with four technical replicates. The coefficient \\
of determination $\left(R^{2}\right)$ was 0.997. \\
b Number of positive samples out of the total number of reactions.
\end{tabular}

copies $\beta$-tubulin gene per ng of gDNA for D. seriata (DAR79990) and $N$. parvum (DAR78998) was 32,211 and 32,488 (data not shown). The size of $D$. seriata and $N$. parvum haploid genomes were reported to be approximately 37.1 and $42.6 \mathrm{mbp}$, respectively (Morales-Cruz et al. 2015), which are equivalent to approximately 39 and $44 \mathrm{fg}$ of DNA, respectively. Therefore, the calculated number of $\beta$-tubulin gene copies for D. seriata (DAR79990) and N. parvum (DAR78998) were 1.2 and 1.3, respectively (data not shown), indicating that the $\beta$-tubulin gene for Botryosphaeriaceae spp. is most likely a single copy gene previously reported for some species of the Dothideomycetes (Zhao et al. 2014). The mean Cq value for the samples containing $5 \mathrm{ng}$ of $D$. seriata $(\mathrm{Cq}=17.30)$ was not significantly different $(P>0.05)$ from the same DNA sample spiked with $1.5 \mathrm{ng}$ of either $C$. ampelina $(\mathrm{Cq}=17.29)$ or E. lata $(\mathrm{Cq}=$ 17.32) gDNA, indicating the qPCR method was not affected by the presence of nontarget DNA (data not shown).

Spore trapping from vineyards. From Griffith, NSW, analyses of 182 spore tape samples collected from June 2014 to May 2015 showed $35(19 \%)$ of the samples were positive for Botryosphaeriaceae, with the highest frequency of spore release observed in September-October 2014 and January 2015 (Fig. 3). The qPCR analyses of the positive samples showed the number of spores per sample ranged from 8 to 430 with the highest number of spores detected in January 2015. From the Hunter Valley, analyses of 195 samples collected from June 2014 to May 2015 showed 35 (18\%) of the samples positive for Botryosphaeriaceae (Fig. 3). The highest frequency of spore release was observed in August-September 2014 and January-March 2015. The qPCR analyses showed the number of spores per sample ranged from 8 to 260 . All positive control tapes ( $N$. luteum conidia) included in each DNA extraction were amplified in each assay while no amplifications were observed on any of the negative control tapes: a) noninoculated tape; and b) tape inoculated with $E$. lata ascospores (data not shown).

\section{Discussion}

The objective of this study was to develop highly specific and sensitive molecular tools for the detection and quantification of spores for several species of Botryosphaeriaceae associated with Botryosphaeria dieback in Australian vineyards. To our knowledge,

Table 5. Determination of the limit of detection (LOD) of the qPCR using different concentrations of genomic DNA of Diplodia seriata and Neofusicoccum parvum

\begin{tabular}{lcc}
\hline fg/reaction & Cq values \pm std dev $^{\mathbf{a}}$ & Signal ratio $^{\mathbf{b}}$ \\
\hline Diplodia seriata (DAR79990) & & \\
$52,500,000$ & $13.99 \pm 0.09$ & $8 / 8$ \\
$5,250,000$ & $17.29 \pm 0.17$ & $8 / 8$ \\
525,000 & $21.05 \pm 0.14$ & $8 / 8$ \\
52,500 & $24.39 \pm 0.23$ & $8 / 8$ \\
5,250 & $29.25 \pm 0.09$ & $8 / 8$ \\
875 & $30.28 \pm 0.20$ & $8 / 8$ \\
525 & $31.62 \pm 0.52$ & $8 / 8$ \\
300 & $32.29 \pm 0.76$ & $8 / 8$ \\
50 & No detection & $0 / 0$ \\
5 & No detection & $0 / 0$ \\
Neofusicoccumparvum (DAR78998) & & \\
$20,000,000$ & $15.49 \pm 0.04$ & $8 / 8$ \\
$2,000,000$ & $18.79 \pm 0.14$ & $8 / 8$ \\
200,000 & $22.26 \pm 0.09$ & $8 / 8$ \\
20,000 & $25.75 \pm 0.16$ & $8 / 8$ \\
2000 & $26.85 \pm 0.45$ & $8 / 8$ \\
1000 & $29.85 \pm 0.45$ & $8 / 8$ \\
200 & $33.82 \pm 0.76$ & $4 / 4$ \\
20 & No detection & $0 / 0$ \\
\hline
\end{tabular}

${ }^{\text {a }}$ Quantification cycles (Cq) at which fluorescence was detected. The $\mathrm{Cq}$ values and corresponding standard deviations $( \pm)$ were derived from the means of two independent assays each with four technical replicates. The coefficient of determination $\left(R^{2}\right)$ was 0.997 .

${ }^{b}$ Number of positive samples out of the total number of reactions. 
this is the first qPCR method developed to target multiple species of Botryosphaeriaceae from environmental samples and spore trap samples collected using a Burkard volumetric spore sampler. The qPCR protocol developed for this study was able to distinguish the target species (in this case 10 Botryosphaeriaceae species) from the other fungal DNA. The quantification of the target DNA for each protocol was not affected by the presence of nontarget DNA in the qPCR reactions.

Previous studies on spore dispersal patterns of Botryosphaeriaceae (Amponsah et al. 2009; Kuntzmann et al. 2009; Úrbez-Torres et al. 2010; Valencia et al. 2015; van Niekerk et al. 2010) relied primarily on conventional techniques such as microscopy and culturing onto artificial media, which are extremely time consuming, less accurate, and less sensitive than molecular tools for detecting these pathogens from environmental samples. In recent years, the use of DNA-based molecular tools has become popular for the detection and quantification of different plant pathogens. Airborne inoculum of Sclerotinia sclerotiorum (Rogers et al. 2009), Leptosphaeria maculans (Van de Wouw et al. 2010) in canola, and Mycosphaerella graminicola in wheat (Duvivier et al. 2013) were successfully quantified using qPCR. This method was also used to quantify inoculum of grapevine pathogens Botrytis cinerea (Diguta et al. 2010), Phaeomoniella chlamydospora, and Phaeacremonium minimum (Martín et al. 2012), and the Pinus negra pathogen, Sphaeropsis sapinea (Luchi et al. 2005). However, none of the primers used in these studies were designed to detect multiple species of pathogens in a single sample. Multispecies primers that were able to detect a low amount of DNA of multiple species of Botryosphaeriaceae has been developed (Ridgway et al. 2011; Spagnolo et al. 2011). However, these primers were designed primarily for conventional PCR that is only semiquantitative. Recently, multiplex qPCR has become popular in quantifying multiple target DNA in a single sample. This technology works by using two to five species-specific primers and their specific probes that are labeled with different fluorophores and combined in a single reaction tube. A multiplex qPCR assay successfully quantified two pathogens (Ph. chlamydospora and P. minimum) from infected grapevine wood samples (Pouzoulet et al. 2013). However, the primers and probes for multiplex PCR are more difficult to design and optimize, as well as more costly when compared with singleplex qPCR (BIO-RAD Laboratories 2006). The qPCR protocols using multispecies primers developed in this study are easier and cheaper options than multiplexPCR but can accurately detect and quantify up to 10 target species in a single sample.

For spore trapping, Melinex tapes (Burkard Scientific, U.K.) coated with petroleum-based adhesive were used to enable the spores to stick to the tape surface. The removal of spores from the sticky surface, however, was difficult and affected the yield of DNA during extractions. The tapes also contain adhesives, other microorganisms, insects, and dust that can be inhibitory to qPCR. Thus, a DNA extraction protocol that can efficiently remove spores from the tapes without compromising the DNA quantity and quality was essential for this study. DNA extraction protocols from spore tapes were previously developed (Duvivier et al. 2013; Rogers et al. 2009), but these methods required reagents that were either not readily available in Australia or hazardous to humans, and required special equipment during handling. In this study, we modified the protocol from the Gentra Puregene (Qiagen, U.S.A.) system that allowed the extraction of DNA from spore tapes using lysing tubes that contain two types of ceramic beads. The beads allowed the rapid removal of the spores from the tape surfaces as well as breaking the cell walls allowing the DNA to be released and isolated. This method was shown to give consistent DNA yield when used for extracting DNA from artificially inoculated tapes and spore trap tape samples from vineyards. This method was also found safe and easy to use and is now used as the standard protocol for extracting DNA from vineyard spore trap tapes.

The multispecies primer (Bot-BtF1 and Bot-BtR1) and hydrolysis probe (Taq-Bot probe) for the qPCR was developed to detect and quantify 10 species of Botryosphaeriaceae commonly associated with Botryosphaeria dieback in Australian vineyards. Specificity tests conducted in Australia demonstrated that all primers were able to amplify the DNA of their corresponding target species, while no PCR products were observed with the DNA of all the other nontarget species tested, including other grapevine fungal pathogens. These results were further validated at SuRDC in Canada using a collection of isolates from various countries, and the validation results confirmed all primers to be highly specific to their target species.

The qPCR primers (Bot-BtF1 and Bot-BtR1) target the $\beta$-tubulin gene, which is reported to occur in single copies in some members of the Dothideomycetes genome (Zhao et al. 2014), making it less sensitive but easier to translate into spore numbers (in this case one copy is one spore). Using a higher DNA template of $7 \mu 1$, the qPCR assay can detect up to seven copies of the gBlocks or 200 to $300 \mathrm{fg}$ of gDNA. The reference haploid genome sizes of $D$. seriata and $N$. parvum are equivalent to 37.1 and $42.6 \mathrm{mbp}$, respectively (Morales-Cruz et al. 2015). Therefore, a uninucleate conidium of these species would contain approximately 39 and 45 fg DNA, respectively. Thus, the detection limit of 200 to $300 \mathrm{fg}$ is equivalent to five to seven spores, which is similar to the detection limit of the gBlocks of seven copies. The sensitivity of the qPCR in this study is similar to the qPCR methods developed for S. sclerotiorum (Rogers et al. 2009) and $P$. minimum (Pouzoulet et al. 2013) with detection limits of 350 and $250 \mathrm{fg}$ of gDNA, respectively, for their respective singlecopy target gene.

Many qPCR studies clone their gene of interest into a bacterial plasmid in order to generate single copies of their target genes, and use these cloned genes as standards (Coy et al. 2014; Duvivier et al. 2013; Lee et al. 2006; Pouzoulet et al. 2013). Instead of cloning, which can be difficult and time consuming, this study used gBlocks, which are synthetic single copies of the target $\beta$-tubulin gene and were used as the qPCR standards. These gBlocks are commercially synthesized by Integrated DNA Technologies (U.S.A.) and are therefore cheap and easy to prepare. In recent years, the use of gBlocks for the construction of standard curves for qPCR has been common in various biological, medical, and ecological studies (Greiman and Tkach 2016; Gunawardana et al. 2014; Lee et al. 2016; Sandkam et al. 2015).

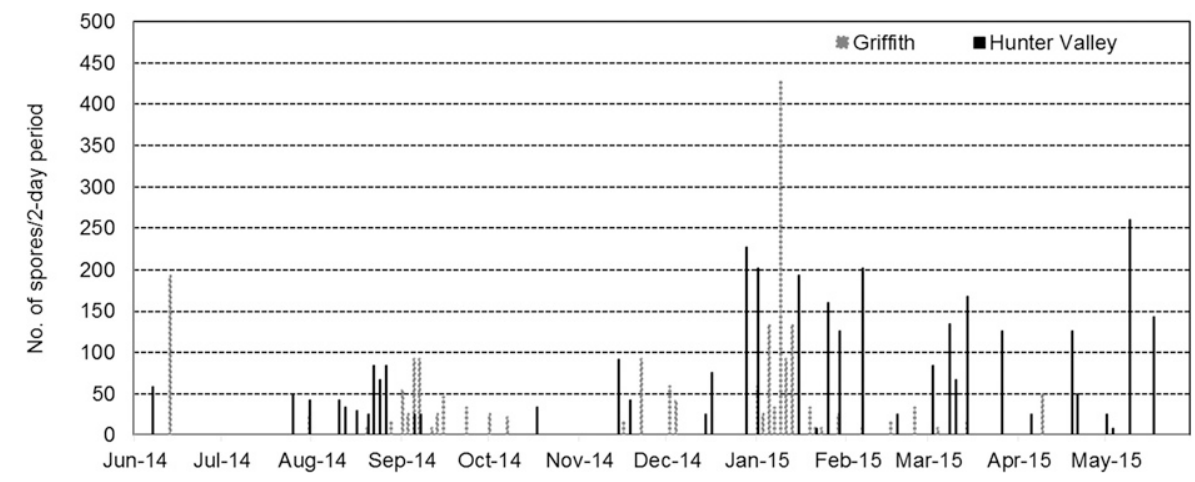

Fig. 3. Number of Botryosphaeriaceae spores trapped per 2-day period in the Hunter Valley and Griffith, New South Wales, Australia, from June 2014 to May 2015. 
The qPCR assay developed in this study was also successful in detecting inoculum of Botryosphaeriaceae from spore tape samples collected from Burkard spore traps placed in vineyards. Analysis of 377 samples from two sampling sites showed $19 \%$ of the samples were positive to nested PCR using multispecies primers. The number of spores detected using qPCR ranged from eight to 430 spores per 2-day period. These results demonstrated that the DNA extraction protocol and qPCR assay developed in this study are highly suitable for detecting and quantifying inoculum of Botryosphaeriaceae for spore trapping studies. To our knowledge, this was the first successful attempt to detect inoculum of Botryosphaeriaceae by qPCR using multispecies primers. Previous studies on monitoring the release of Botryosphaeriaceae spores using glass slides coated with petroleum jelly and rainwater traps was found to be time consuming and only yielded semi-quantitative data (Amponsah et al. 2009; Kuntzmann et al. 2009; Úrbez-Torres, et al. 2010; van Niekerk et al. 2010).

Up to 430 spores were detected on spore tape samples from 2-day periods from Australian vineyards in this study. The number of spores trapped were relatively low when compared with similar spore trapping studies in other countries. In California, the peaks of spores detected using Burkard spore traps were greater than 1,000 spores/day in Sonoma County, although the numbers trapped in Monterey County were much lower, peaking at $\sim 300$ spores/day (Úrbez-Torres et al. 2010). In South Africa, the Quest volumetric spore trap was able to detect up to $\sim 700$ spores in one day, although the spore numbers were lower ( $\sim 200$ spores/day) the previous year from the same vineyard (van Niekerk et al. 2010). The differences in spore numbers detected in this study and those reported from other countries may be attributed to varying climatic conditions in different regions over different years. Since Australian wine regions cover a wide geographical area with highly diverse climates, a comprehensive spore trapping study is being undertaken in major wine regions over several years to provide information on the spore release patterns of these pathogens specific to each climatic region. It is also important to note that the studies done in California and South Africa described above used conventional techniques including microscopy and plating and not molecular methods. The placement of traps up to $10 \mathrm{~m}$ from the closest inoculum source in this study may have also contributed to the lower number of spores detected compared with previous studies, since Botryosphaeriaceae spores are known to be primarily splash-dispersed, and thus only travel short distances (Amponsah et al. 2009; Kuntzmann et al. 2009; Úrbez-Torres, et al. 2010; van Niekerk et al. 2010). Baskarathevan et al. (2013) also showed that conidia produced by $N$. luteum and $N$. parvum marker-strains moved up to $2 \mathrm{~m}$ away from a single inoculum source in a single rain event and were influenced by wind speed and direction. The rainwater runoff traps in New Zealand (Amponsah et al. 2009) and microscope slide traps in France (Kuntzmann et al. 2009) installed in vine trunks and cordons were able to detect peaks in the thousands of Botryosphaeriaceae spores each day.

The multispecies primers developed in this research are rapid and inexpensive tools to detect and quantify multiple species of Botryosphaeriaceae in a single qPCR assay. However, due to its multiple targets, this assay cannot discriminate the different species within a sample. Identification of the different species from individual spore trap tapes will determine the most prevalent species that contribute to the spore release in each region. Ridgway et al. (2011) developed a method using a combination of standard PCR and single-stranded conformation polymorphism (SSCP) analysis to resolve the identities of the mixed Botryosphaeriaceae species amplified by their multispecies primers. A DNA-based molecular diagnostic tool (DNA macroarray) was shown to detect several species of pathogens causing young vine decline from planting material in a single nursery, including those causing Petri/Esca disease and Black foot (Úrbez-Torres et al. 2014a, b). The PCR-SSCP system or the DNA macroarray can potentially be used in the future for identification of different grapevine trunk disease pathogens present in spore trap tape samples.

\section{Acknowledgments}

The authors would like to thank the Riverina Marketing Board and McWilliams Wine for their technical support in the spore trap sample collection.

\section{Literature Cited}

Amponsah, N. T., Jones, E. E., Ridgway, H. J., and Jaspers, M. V. 2009. Rain water dispersal of Botryosphaeria conidia from infected grapevines. N. Z. Plant Prot. 62:228-233.

Baskarathevan, J., Jaspers, M. V., Jones, E. E., and Ridgway, H. J. 2013. Development of isolate-specific markers for Neofusicoccum parvum and $N$. luteum and their use to study rainwater splash dispersal in the vineyard. Plant Pathol. 62:501-509.

BIO-RAD Laboratories. 2006. Real-time PCR applications guide, Bulletin 5279 http://www.bio-rad.com/webroot/web/pdf/lsr/literature/Bulletin_5279.pdf

Bustin, S. A., Benes, V., Garson, J. A., Hellemans, J., Huggett, J., Kubista, M. Mueller, R., Nolan, T., Pfaffl, M. W., Shipley, G. L., Vandesompele, J., and Wittwer, C. T. 2009. The MIQE guidelines: minimum information for publication of quantitative real-time PCR experiments. Clin. Chem. 55: 611-622.

Coy, M. R., Hoffmann, M., Kingdom Gibbard, H. N., Kuhns, E. H., Pelz-Stelinski, K. S., and Stelinski, L. L. 2014. Nested-quantitative PCR approach with improved sensitivity for the detection of low titer levels of Candidatus Liberibacter asiaticus in the Asian citrus psyllid, Diaphorina citri Kuwayama. J. Microbiol. Methods 102:15-22.

Diguta, C. F., Rousseaux, S., Weidmann, S., Bretin, N., Vincent, B., GuillouxBenatier, M., and Alexandre, H. 2010. Development of a qPCR assay for specific quantification of Botrytis cinerea on grapes. FEMS Microbiol. Lett. 313:81-87.

Duvivier, M., Dedeurwaerder, G., De Proft, M., Moreau, J., and Legreve, A. 2013. Real-time PCR quantification and spatio-temporal distribution of air-borne inoculum of Mycosphaerella graminicola in Belgium. Eur. J. Plant Pathol. 137:325-341.

Glass, N. L., and Donaldson, G. C. 1995. Development of primer sets designed for use with the PCR to amplify conserved genes from filamentous ascomycetes. Appl. Environ. Microbiol. 61:1323-1330.

Greiman, S. E., and Tkach, V. V. 2016. The numbers game: quantitative analysis of Neorickettsia sp. propagation through complex life cycle of its digenean host using realtime qPCR. Parasitol. Res. 115:2779-2788.

Gunawardana, M., Chang, S., Jimenez, A., Holland-Moritz, D., Holland-Moritz, H., La Val, T. P., Lund, C., Mullen, M., Olsen, J., Sztain, T. A., Yoo, J., Moss, J. A., and Baum, M. M. 2014. Isolation of PCR quality microbial community DNA from heavily contaminated environments. J. Microbiol. Methods 102:1-7.

Kumar, S., Stecher, G., and Tamura, K. 2016. MEGA7: Molecular evolutionary genetics analysis version 7.0 for bigger datasets. Mol. Biol. Evol. 33. 1870-1874.

Kuntzmann, P., Villaume, S., and Bertsch, C. 2009. Conidia dispersal of Diplodia species in a French vineyard. Phytopathol. Mediterr. 48:150-154.

Lee, C., Kim, J., Shin, S. G., and Hwang, S. 2006. Absolute and relative QPCR quantification of plasmid copy number in Escherichia coli. J. Biotechnol. 123:273-280.

Lee, J., Foong, Y. H., Musaitif, I., Tong, T., and Jefcoate, C. 2016. Analysis of specific RNA in cultured cells through quantitative integration of q-PCR and N-SIM single cell FISH images: Application to hormonal stimulation of StAR transcription. Mol. Cell. Endocrinol. 429:93-105.

Luchi, N., Capretti, P., Surico, G., Orlando, C., Pazzagli, M., and Pinzani, P. 2005 A real-time Quantitative PCR assay for the detection of Sphaeropsis sapinea from inoculated Pinus nigra shoots. J. Phytopathol. 153:37-42.

Martín, M. T., Cobos, R., Martín, L., and López-Enríquez, L. 2012. Real-Time PCR Detection of Phaeomoniella chlamydospora and Phaeoacremonium aleophilum. Appl. Environ. Microbiol. 78:3985-3991.

Morales-Cruz, A., Amrine, K. C. H., Blanco-Ulate, B., Lawrence, D. P., Travadon, R., Rolshausen, P. E., Baumgartner, K., and Cantu, D. 2015. Distinctive expansion of gene families associated with plant cell wall degradation, secondary metabolism, and nutrient uptake in the genomes of grapevine trunk pathogens. BMC Genomics 16:469.

Pitt, W. M., Huang, R., Steel, C. C., and Savocchia, S. 2010. Identification, distribution and current taxonomy of Botryosphaeriaceae species associated with grapevine decline in New South Wales and South Australia. Aust. J. Grape Wine Res. 16:258-271.

Pitt, W. M., Úrbez-Torres, J. R., and Trouillas, F. P. 2013. Dothiorella vidmadera, a novel species from grapevines in Australia and notes on Spencermartinsia. Fungal Divers. 61:209-219.

Pouzoulet, J., Mailhac, N., Couderc, C., Besson, X., Daydé, J., Lummerzheim, M. and Jacques, A. 2013. A method to detect and quantify Phaeomoniella chlamydospora and Phaeoacremonium aleophilum DNA in grapevine-wood samples. Appl. Microbiol. Biotechnol. 97:10163-10175.

Pouzoulet, J., Rolshausen, P. E., Schiavon, M., Bol, S., Travadon, R., Lawrence, D. P., Baumgartner, K., Ashworth, V. E., Pierron, R. J. G., Besson, X., and Jacques, A. 2017. A method to detect and quantify Eutypa lata and Diplodia seriata-complex DNA in grapevine pruning wounds. Plant Dis. 101: 1470-1480. 
Qiu, Y., Steel, C. C., Ash, G. J., and Savocchia, S. 2011. Survey of Botryosphaeriaceae associated with grapevine decline in the Hunter Valley and Mudgee grape growing regions of New South Wales. Australas. Plant Pathol. 40:1-11.

Rathnayake, R. M. S. P., Savocchia, S., Schmidtke, L. M., and Steel, C. C. 2018. Characterisation of Aureobasidium pullulans isolates from Vitis vinifera and potential biocontrol activity for the management of bitter rot of grapes. Eur. J. Plant Pathol.

Ridgway, H. J., Amponsah, N. T., Brown, D. S., Baskarathevan, J., Jones, E. E., and Jaspers, M. V. 2011. Detection of botryosphaeriaceous species in environmental samples using a multi-species primer pair. Plant Pathol. 60: 1118-1127.

Rogers, S. L., Atkins, S. D., and West, J. S. 2009. Detection and quantification of airborne inoculum for Sclerotinia sclerotiorum using quantitative PCR. Plant Pathol. 58:324-331.

Sandkam, B., Young, C. M., and Breden, F. 2015. Beauty in the eyes of the beholders: colour vision is tuned to mate preference in the Trinidadian guppy (Poecilia reticulata). Mol. Ecol. 24:596-609.

Savocchia, S., Steel, C. C., Stodart, B. J., and Somers, A. 2007. Pathogenicity of Botryosphaeria species isolated from declining grapevines in sub-tropical regions of Eastern Australia. Vitis 46:27-32.

Serra, S., Mannoni, M. A., and Ligios, V. 2008. Studies on the susceptibility of pruning wounds to infection by fungi involved in grapevine wood diseases in Italy. Phytopathol. Mediterr. 47:234-246.

Spagnolo, A., Marchi, G., Peduto, F., Phillips, A. J. L., and Surico, G. 2011. Detection of Botryosphaeriaceae species within grapevine woody tissues by nested PCR, with particular emphasis on the Neofusicoccum parvum/N. ribis complex. Eur. J. Plant Pathol. 129:485-500.

Trouillas, F. P., Pitt, W. M., Sosnowski, M. R., Huang, R., Peduto, F., Loschiavo, A., Savocchia, S., Scott, E. S., and Gubler, W. D. 2011. Taxonomy and DNA phylogeny of Diatrypaceae associated with Vitis vinifera and other woody plants in Australia. Fungal Divers. 49:203-223.

Úrbez-Torres, J. R. 2011. The status of Botryosphaeriaceae species infecting grapevines. Phytopathol. Mediterr. 50:S5-S45.

Úrbez-Torres, J. R., Battany, M., Bettiga, L. J., Gispert, C., McGourty, G., Roncoroni, J., Smith, R. J., Verdegaal, P., and Gubler, W. D. 2010. Botryosphaeriaceae species spore-trapping studies in California vineyards. Plant Dis. 94:717-724
Urbez-Torres, J. R., and Gubler, W. D. 2011. Susceptibility of grapevine pruning wounds to infection by Lasiodiplodia theobromae and Neofusicoccum parvum. Plant Pathol. 60:261-270.

Úrbez-Torres, J. R., Haag, P., Bowen, P., and O'Gorman, D. T. 2014a. Grapevine Trunk Diseases in British Columbia: Incidence and characterization of the fungal pathogens associated with black foot disease of grapevine. Plant Dis. 98:456-468.

Úrbez-Torres, J. R., Haag, P., Bowen, P., and O'Gorman, D. T. 2014b. Grapevine Trunk Diseases in British Columbia: Incidence and characterization of the fungal pathogens associated with esca and Petri diseases of grapevine. Plant Dis. 98:469-482.

Úrbez-Torres, J. R., and O'Gorman, D. T. 2016. Grapevine trunk diseases studies in British Columbia. Can. J. Plant Pathol. 39:110.

Valencia, D., Torres, C., Camps, R., Lopez, E., Celis-Diez, J. L., and Besoain, X. 2015. Dissemination of Botryosphaeriaceae conidia in vineyards in the semiarid Mediterranean climate of the Valparaíso Region of Chile. Phytopathol. Mediterr. 54:394-402.

Van de Wouw, A. P., Stonard, J. F., Howlett, B. J., West, J. S., Fitt, B. D. L., and Atkins, S. D. 2010. Determining frequencies of avirulent alleles in airborne Leptosphaeria maculans inoculum using quantitative PCR. Plant Pathol. 59: 809-818.

van Niekerk, J. M., Calitz, F. J., Halleen, F., and Fourie, P. H. 2010. Tempora spore dispersal patterns of grapevine trunk pathogens in South Africa. Eur. J. Plant Pathol. 127:375-390.

van Niekerk, J. M., Calitz, F. J., Halleen, F., and Fourie, P. H. 2011. Temporal susceptibility of grapevine pruning wounds to trunk pathogen infection in South African grapevines. Phytopathol. Mediterr. 50:S139-S150.

White, T. J., Bruns, T., Lee, S., and Taylor, J. 1990. Amplification and direct sequencing of fungal ribosomal RNA genes for phylogenetics. Pages 315-322 in: PCR protocols: A guide to methods and applications. M. A. Innis, D. H. Gelfand, J. J. Sninski, and T. J. White, eds. Academic Press, San Diego.

Wunderlich, N., Ash, G. J., Steel, C. C., Raman, H., and Savocchia, S. 2011 Association of Botryosphaeriaceae grapevine trunk disease fungi with the reproductive structures of Vitis vinifera. Vitis 50:89-96.

Zhao, Z., Liu, H., Luo, Y., Zhou, S., An, L., Wang, C., Jin, Q., Zhou, M., and $\mathrm{Xu}$, J. 2014. Molecular evolution and functional divergence of tubulin superfamily in the fungal tree of life. Sci. Rep. 4:6746. 